(c) American Dairy Science Association, 2005.

\title{
Effects of Dietary $\alpha$-Amylase on Metabolism and Performance of Transition Dairy Cows ${ }^{\star} \dagger$
}

\author{
J. M. DeFrain, ${ }^{1, \ddagger}$ A. R. Hippen, ${ }^{1}$ K. F. Kalscheur, ${ }^{1}$ and J. M. Tricarico ${ }^{2}$ \\ ${ }^{1}$ Dairy Science Department South Dakota State University, Brookings 57007 \\ ${ }^{2}$ Alltech, Inc., Nicholasville, KY 40356
}

\begin{abstract}
Twenty-four multiparous Holstein cows [body weight, $759 \mathrm{~kg}$ ( $\mathrm{SD}=30 \mathrm{~kg}$ ); body condition score, 3.2 $(\mathrm{SD}=0.13)]$ were used in a randomized complete block design to determine the effect of feeding $\alpha$-amylase during the transition period on rumen fermentation, key metabolic indicators, and lactation performance. Cows were assigned to either a control diet or the control diet supplemented with $\alpha$-amylase (662 fungal amylase units per gram, AMA) at $0.1 \%$ of diet dry matter (DM). Experimental diets were fed from $21 \mathrm{~d}$ before expected calving through $21 \mathrm{~d}$ in milk. From 22 to $70 \mathrm{~d}$ in milk, all cows were fed a similar lactation cow diet. Average pre- and postpartum DM intakes were 12.4 and $17.8 \mathrm{~kg} /$ $\mathrm{d}$, respectively, and did not differ between treatments; however, DM intakes during the last week prepartum decreased to a greater degree in AMA than control cows compared with wk -2 . Supplementing diets with $\alpha$-amylase tended to increase proportions of ruminal butyrate prepartum but not postpartum. Treatment differences were not detected for concentrations of insulin in plasma and lipid and glycogen in liver tissue. Prepartum, concentrations of $\beta$-hydroxybutyrate and nonesterified fatty acids were increased in cows fed AMA compared with the control diet. Postpartum, concentrations of glucose in plasma tended to be increased by feeding AMA. Increased plasma $\beta$-hydroxybutyrate and nonesterified fatty acids pre- but not postpartum and a tendency for increased plasma glucose postpartum demonstrate shifting reliance from lipid- to carbohydrate-based metabolism postpartum in cows fed $\alpha$ amylase.
\end{abstract}

(Key words: amylase, $\beta$-hydroxybutyrate, transition dairy cow)

Received January 25, 2005.

Accepted August 9, 2005.

Corresponding author: Arnold R. Hippen; e-mail: arnold_ hippen@sdstate.edu.

*Published with the approval of the director of the South Dakota Agricultural Experiment Station as publication no. 3459 of the journal series.

$\dagger$ Partially supported by Alltech, Inc., Nicholasville, KY.

†Current address: Hubbard Feeds Inc., Mankato, MN 56002.
Abbreviation key: AMA $=\alpha$-amylase-supplemented diet.

\section{INTRODUCTION}

Recent research on exogenous enzymes has been directed toward improving ruminal fiber digestion. Early reports on the application of enzymes in ruminant diets, however, involved amylases (Burroughs et al., 1960; Ralston et al., 1962). Little interest has been demonstrated in the use of amylase as the ruminal digestion of starch is not considered limiting, and rapid digestion of starch in the rumen can result in ruminal acidosis and decrease intake and production (Owens et al., 1998). Huntington (1997), however, indicated the digestion of starch in the rumen is more beneficial than postruminal digestion because ruminal digestion increases microbial protein outflow from the rumen thus providing rational to enhance ruminal starch digestibility. Paradoxically, the digestion of starch in the rumen (vs. intestine) can cause a loss of energy through heat, $\mathrm{CH}_{4}$, and $\mathrm{H}_{2}$ (Rowe et al., 1999).

Observed improvements in ruminal digestion and lactation performance of dairy cattle fed fibrolytic enzyme preparations during early lactation advocate the need for investigating starch-digesting enzyme supplements. In general, transition dairy cows are forced to quickly adapt to highly fermentable diets to decrease the degree of negative energy balance typically observed during the immediate postpartum period. Dietary alterations that increase fermentability have been demonstrated to affect the morphology of the rumen papillae (Dirksen et al., 1985) and may be valuable for providing more energy from the transition dairy cow's diet through increased VFA production and absorption. In addition, butyrate-stimulating feed ingredients, such as lactose, have demonstrated increased rumen papillation. Xu and Allen (1998) demonstrated increased growth rates for length, width, and overall greater surface area of ruminal papillae in nonpregnant, nonlactating dairy cows fed butyrate-stimulating diets containing $43 \%$ lactose (DM basis) compared with $43 \%$ corn. Feeding $\alpha$-amylase (Hristov et al., 2000; Tricarico et al., 2002) has also been observed to increase 
concentrations of ruminal butyrate; however, no reports exist of the effects of feeding amylase on transition cow performance.

Therefore, our objectives were to determine the effect of feeding an $\alpha$-amylase preparation during the transition period on rumen fermentation, key metabolic indicators, and lactation performance. It was hypothesized that alteration of rumen fermentation profiles would improve energy balance and performance of transition dairy cows.

\section{MATERIALS AND METHODS}

\section{Experimental Design and Feeding and Management of Cows}

The experiment was conducted from September 2003 through July 2004 at the South Dakota State University Dairy Teaching and Research Facility (Brookings, SD). Animal care and use was according to a protocol approved by the South Dakota State University Institutional Animal Care and Use Committee. Twenty-four multiparous Holstein cows were used to examine the effects of feeding an $\alpha$-amylase enzyme preparation (Amaize, batch no. 224638-8, Alltech, Inc., Nicholasville, KY) on DMI, milk production and composition, blood metabolites, and liver composition. Treatments were arranged as a randomized block design and blocked by expected calving date.

At $28 \mathrm{~d}$ prior to expected calving date, cows were assigned to their respective treatment diet (Table 1), either control or $\alpha$-amylase (AMA) at $0.1 \%$ of diet DM. The $\alpha$-amylase preparation is a fermentation extract from Saccharomyces cerevisiae fermentation solubles and Aspergillus oryzae. It was analyzed to contain (DM basis) $28.6 \% \mathrm{CP}, 14.5 \%$ ether extract, $3.8 \%$ crude fiber, $8.1 \%$ ash, and 662 fungal amylase units/g. One fungal amylase unit is the amount of enzyme required to dextrinize soluble starch at the rate of $1 \mathrm{~g} / \mathrm{h}$ at $30^{\circ} \mathrm{C}$ and $\mathrm{pH} 4.8$.

Cows were housed on a bedded pack prepartum and adapted to the Calan Broadbent feeding system (American Calan, Inc., Northwood, NH) 1 wk before initiation of treatments. Experimental diets were offered starting at $21 \mathrm{~d}(\mathrm{SD}=4.9)$ prepartum. Cows were housed in individual maternity pens from parturition until milk was tested and found to be free of antibiotic residues, at which time the cows were moved to free-stall housing also equipped with a Calan door system. Thus, individual feed intakes and refusals were measured from 28 d prepartum until $28 \mathrm{~d}$ postpartum. At 21 DIM, experimental diets were discontinued and from 22 to 70 DIM, all cows were fed a common lactation cow diet. Ingredient and nutrient composition of diets are shown in Ta-
Table 1. Ingredient composition of diets. ${ }^{1}$

\begin{tabular}{|c|c|c|c|}
\hline Ingredient, $\%$ of diet DM & $\begin{array}{l}-21 \text { to } \\
0 \text { DIM }\end{array}$ & $\begin{array}{l}1 \text { to } \\
21 \text { DIM }\end{array}$ & $\begin{array}{l}22 \text { to } \\
70 \mathrm{DIM}^{2}\end{array}$ \\
\hline Brome grass hay & 14.3 & - & - \\
\hline Alfalfa hay & 14.5 & 8.3 & 15.3 \\
\hline Alfalfa haylage & - & 14.5 & 6.6 \\
\hline Corn silage, processed & 40.2 & 27.9 & 24.9 \\
\hline Whole cottonseed & 2.0 & 8.6 & 7.9 \\
\hline Wet distillers grains & - & 3.6 & - \\
\hline Dried distillers grains & - & - & 4.6 \\
\hline Corn, high moisture & - & - & 17.9 \\
\hline Corn grain, ground & 17.7 & 25.2 & 7.6 \\
\hline Energizer $4-19 \mathrm{~W}^{3}$ & - & - & 4.2 \\
\hline Soybean meal, $44 \%$ & 1.81 & 4.88 & 2.45 \\
\hline SoyChlor $16-7^{4}$ & 6.63 & - & - \\
\hline SoyPlus ${ }^{4}$ & 1.80 & 4.24 & 4.55 \\
\hline Limestone & 0.36 & 1.07 & 0.52 \\
\hline Dicalcium phosphate & - & 0.19 & - \\
\hline Sodium bicarbonate & - & 0.59 & 0.57 \\
\hline Fish meal, menhaden & - & - & 0.40 \\
\hline Pork meat and bone meal & - & - & 1.21 \\
\hline Yeast culture $^{5}$ & - & - & 0.21 \\
\hline Magnesium oxide & - & 0.24 & 0.17 \\
\hline Salt & - & 0.24 & 0.50 \\
\hline Vitamin A, D, and E premix & $0.65^{\mathrm{a}}$ & $0.31^{b}$ & $0.31^{b}$ \\
\hline Urea & 0.02 & 0.02 & 0.10 \\
\hline $4-\mathrm{Plex}^{6}$ & 0.07 & 0.07 & 0.05 \\
\hline Vitamin E premix ${ }^{7}$ & - & 0.05 & 0.02 \\
\hline
\end{tabular}

${ }^{1}$ Amylase was fed at $0.10 \%$ of diet DM to cows fed AMA.

${ }^{2}$ All cows were fed the same diet from 22 to 70 DIM.

${ }^{3}$ Quality Liquid Feeds, Inc., Dodgeville, WI. Liquid mixture of cane molasses, condensed whey, and tallow (assay DM basis: $12.9 \% \mathrm{CP}$, $61 \%$ fat).

${ }^{4}$ West Central Soy, Ralston, IA. SoyChlor 16-7 is a heat-processed soybean meal treated with HCl (assay DM basis: $23 \%$ CP, $53 \%$ RUP, $10.3 \% \mathrm{Cl}$ ). SoyPlus is a heat-processed soybean meal (assay DM basis: $50 \%$ CP, $60 \%$ RUP).

${ }^{5}$ Diamond V XP, Diamond V Mills, Inc., Cedar Rapids, IA. Contained Saccharomyces cerevisiae yeast and the media on which it was grown.

${ }^{6} 4$-Plex, Zinpro Corp., Eden Prairie, MN; Zn and Mn methionine complex, $\mathrm{Cu}$ lysine complex, and Co glucoheptonate.

${ }^{7}$ Contained 44,092 IU of vitamin E per kg.

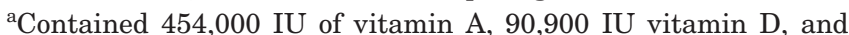
3,636 , IU of vitamin $\mathrm{E}$ per $\mathrm{kg}$.

${ }^{\mathrm{b}}$ Contained 909,000 IU of vitamin A, 182,000 IU vitamin D, and 2,424 , IU of vitamin $\mathrm{E}$ per $\mathrm{kg}$.

bles 1 and 2, respectively. Diets were formulated to comply with recommendations from NRC (2001).

\section{Measurements and Collection of Samples}

Diets were mixed and fed daily at $0600 \mathrm{~h}$ for ad libitum consumption as a TMR. Refusals were measured, recorded, and discarded before feeding daily and amounts fed were adjusted to ensure a $10 \%$ feed refusal. To measure initial and carryover effects of feeding amylase, feed intakes were monitored from -28 to $28 \mathrm{~d}$ postpartum. Samples of diets were collected weekly, frozen at $-20^{\circ} \mathrm{C}$, and composited monthly. The composites were sent in triplicate to Dairyland Laboratories 
Table 2. Nutrient composition of diets. ${ }^{1}$

\begin{tabular}{lccc}
\hline & -21 to & 1 to & 22 to \\
Nutrient & 0 DIM & 21 DIM & $70 \mathrm{DIM}^{2}$ \\
\hline $\mathrm{DM}, \%$ as fed & 50.3 & 48.9 & 48.7 \\
$\mathrm{CP}, \%$ & 14.3 & 18.0 & 17.8 \\
$\mathrm{NE}_{\mathrm{L}}{ }^{3}, \mathrm{Mcal} / \mathrm{kg}$ & 1.62 & 1.68 & 1.68 \\
$\mathrm{ADF}, \%$ & 23.7 & 21.2 & 19.2 \\
$\mathrm{NDF}, \%$ & 36.8 & 32.3 & 31.7 \\
NFC, $\%$ & 37.6 & 37.5 & 36.5 \\
Starch, \% & 23.0 & 25.0 & 29.0 \\
Ether extract, \% & 4.1 & 5.3 & 6.6 \\
Ash, \% & 7.3 & 7.0 & 7.4 \\
Ca, \% & 1.02 & 1.19 & 1.12 \\
$\mathrm{P}, \%$ & 0.38 & 0.42 & 0.48 \\
$\mathrm{Mg}, \%$ & 0.51 & 0.50 & 0.46 \\
$\mathrm{~K}, \%$ & 1.25 & 1.39 & 1.36 \\
$\mathrm{Na}, \%$ & 0.16 & 0.34 & 0.48 \\
$\mathrm{Cl}, \%$ & 0.96 & 0.40 & 0.58 \\
$\mathrm{~S}, \%$ & 0.21 & 0.27 & 0.29 \\
$\mathrm{DCAD},{ }^{5} \mathrm{mEq} / \mathrm{kg}$ of DM & 13 & 223 & 212 \\
\hline
\end{tabular}

${ }^{1}$ Values are based upon nutrient analyses of diets and actual mean DMI by treatment.

${ }^{2}$ All cows were fed the same diet from 22 to 70 DIM.

${ }^{3}$ Calculated using NRC (2001).

${ }^{4} \mathrm{NFC}=100-(\% \mathrm{NDF}+\% \mathrm{CP}+\%$ ether extract $+\%$ ash $)$

${ }^{5} \mathrm{DCAD}=$ dietary cation-anion difference: $[(\mathrm{Na}+\mathrm{K})-(\mathrm{Cl}+\mathrm{S})]$ in milliequivalents per kilogram of DM.

(Arcadia, WI) for analysis. Body weight and BCS (1 to 5 in 0.25 increments; Wildman et al., 1982) were recorded on 2 consecutive days, $4 \mathrm{~h}$ after feeding on $\mathrm{d} 21$ before expected calving date, at parturition, and at 28 and 70 DIM by the same 3 individuals throughout the experiment. Calf birth weights and calving difficulty scores were recorded $(1=$ no problem; $2=$ slight problem; $3=$ needed assistance; $4=$ considerable force; $5=$ cesarean). Cows were milked at 0600, 1400, and 2100 $\mathrm{h}$, and milk yield was recorded until $70 \mathrm{~d}$ of lactation. Milk samples were collected on d 7, 14, and 21 of lactation from all 3 milkings each day and were preserved with bronopol and natamycin (Broad Spectrum Microtabs II, D\&F Control Systems, Inc., Dublin, CA). Incidences of milk fever, metritis, displaced abomasum, mastitis, and foot ailments were recorded during the experiment.

Target day and actual day of blood sampling relative to calving were -21 and -20 (SD = 1.6), -14 and -13.4 $(\mathrm{SD}=1.6),-7$ and $-7.3(\mathrm{SD}=1.8),-2$ and $-2.8(\mathrm{SD}=$ 1.1), 2 and $1.8(\mathrm{SD}=0.9), 7$ and $7.0(\mathrm{SD}=0.9), 14$ and $14.1(\mathrm{SD}=0.9), 21$ and $20.9(\mathrm{SD}=1.0)$, and 28 and $27.8(\mathrm{SD}=0.7)$, respectively. Approximately $4 \mathrm{~h}$ after feeding, blood was sampled from a coccygeal vessel into 2 evacuated tubes (Becton Dickinson and Co., Franklin Lakes, NJ) containing K-EDTA and sodium fluoride. Samples were immediately placed on ice and transported to the laboratory where they were centrifuged $(500 \times \mathrm{g})$ and plasma was harvested and stored at $-20^{\circ} \mathrm{C}$ until further analysis. Ruminal fluid was collected at $21(\mathrm{SD}=4.6)$ and $7(\mathrm{SD}=4.1) \mathrm{d}$ before expected calving date and $7(\mathrm{SD}=1.0) \mathrm{d}$ postpartum $4 \mathrm{~h}$ after feeding by applying vacuum pressure to an esophageal tube fitted with a suction strainer. To minimize saliva contamination, approximately $250 \mathrm{~mL}$ of rumen fluid was discarded before sample collection. A 10-mL sample was mixed with $2 \mathrm{~mL}$ of $25 \%$ (wt/vol) metaphosphoric acid and frozen at $-20^{\circ} \mathrm{C}$ until analyzed for concentrations of VFA and $\mathrm{NH}_{3}-\mathrm{N}$. Liver tissue was collected by trocar and aspiration between the 11th and 12th rib (Smith et al., 1997) approximately $4 \mathrm{~h}$ after feeding on $\mathrm{d} 7$ and 14 [actual days were $7.3(\mathrm{SD}=1.0)$ and $14.1(\mathrm{SD}=$ 0.9)] of lactation. Samples were blotted to remove any residual blood, split into 2 equal aliquots, placed into cryovials, immediately submerged in liquid nitrogen, and transported to the laboratory where they were frozen at $-80^{\circ} \mathrm{C}$ until analysis.

\section{Laboratory Analyses}

Samples of diets were dried at $55^{\circ} \mathrm{C}$ in a forced-air oven and allowed to air-equilibrate before being ground to pass a 2-mm screen of a standard Wiley mill (model 3; Arthur H. Thomas Co., Philadelphia, PA). Samples were made into composites by diet (prepartum, postpartum, and lactation) and month and analyzed for DM $\left(105^{\circ} \mathrm{C}\right.$ for $24 \mathrm{~h}$ ), CP (AOAC, 1997) using a LECO-428 combustion analyzer (LECO Corp., St. Joseph, MI), and ether extract (AOAC, 1997). Neutral detergent fiber and ADF were measured using the Ankom A200 (Ankom Technology Corp., Fairport, NY) filter bag technique. Determinations of ADF were according to AOAC (method $973.18 \mathrm{C}$; 1997) whereas NDF was according to Van Soest et al. (1991) with the addition of $4 \mathrm{~mL}$ of $\alpha$-amylase and $20 \mathrm{~g}$ of sodium sulfite. Starch was measured as dextrose after treating samples with glucoamylase using a YSI 2700 Select Biochemistry Analyzer (Yellow Springs, OH; Holm et al., 1986). Minerals were quantified according to AOAC methods (985.01; 1997) using an inductively coupled plasma spectrometer (Thermo Jarrell Ash, Franklin, MA).

Milk compositional analysis was conducted by Heart of America DHI Laboratory (Manhattan, KS) according to approved procedures of AOAC (1990). Composites of samples, by day, were analyzed for true protein, fat, lactose (near infrared spectroscopy; Bentley 2000 Infrared Milk Analyzer, Bentley Instruments, Chaska, MN), MUN (a modified Berthelot reaction; ChemSpec 150 Analyzer, Bentley Instruments), and SCC (flow cytometer laser (Somacount 500, Bentley Instruments). The SNF was calculated.

Plasma samples were thawed and concentrations of glucose were determined using glucose oxidase (Sigma 
kit \#315, Sigma Diagnostics, St. Louis, MO) according to the procedures of Trinder (1969). Concentration of BHBA in plasma was determined (Pointe Scientific, Inc., Lincoln Park, MI) following the methods of Williamson et al. (1962) and plasma NEFA concentrations were determined using a colorimetric assay (NEFA-C Kit, Wako Chemicals, Richmond, VA), following modifications by Johnson and Peters (1993). Insulin was quantified by solid-phase radioimmunoassay (Coat-ACount, Diagnostic Products Corp., Los Angeles, CA) with an intraassay CV of $1.6 \%$. Samples of liver tissue were analyzed for total lipid and glycogen as described by Mills et al. (1986) and Derling et al. (1987), respectively.

\section{Statistical Analyses}

Effects of treatments on incidences of health disorders were not analyzed for statistical differences because of insufficient replication; however, all cows experiencing disorders were included in the data set. Two cows fed the control diet and 2 fed AMA gave birth to twins. One of these cows (control) required cesarean section. In addition, of the 2 control cows, one was diagnosed with metritis at 10 DIM and the other was treated for a retained placenta. None of the cows fed AMA that twinned received any treatment for either metritis or retained placenta. One cow fed the control diet was treated for mastitis at 65 DIM. No other health disorder events were noted.

The experiment was a randomized complete block design based upon expected calving date. Milk yield and DMI data were reduced to weekly means for statistical analysis. Milk production data collected on the day of calving were not included in the data set because of the inherent difficulties associated with data collected on the day of calving. Data were analyzed as repeated measures using PROC MIXED (Littell et al., 1996) of SAS software (version $8.1 ; 2001$ ). For each variable, cow was subjected to 4 covariance structures: autoregressive order 1, toeplitz, variance component, and compound symmetry. On average, the structure yielding the Akaike's information criterion closest to zero was variance component and autoregressive order 1 . For variables measured over time, the model included treatment, time (week or day depending on the variable), and 2-way interactions as fixed effects. The random effect was diet nested within cow. The method of Kenward-Rogers was used for calculation of denominator degrees of freedom for $F$-tests. Covariates of initial BW and BCS, days on treatment, and previous 305-d mature equivalent milk yield were included for all data sets. Covariates and interactions were dropped from the model one at a time, starting with the least signifi-
Table 3. Previous 305-d mature equivalent milk, days on treatment, BW, BCS, calf birth weights, calving difficulty, and prepartum DMI of cows fed a control diet and a diet supplemented with $\alpha$-amylase (AMA).

\begin{tabular}{|c|c|c|c|c|}
\hline \multirow[b]{2}{*}{ Item } & \multicolumn{2}{|c|}{ Diet } & \multirow[b]{2}{*}{ SEM } & \multirow[b]{2}{*}{$P^{1}$} \\
\hline & Control & AMA & & \\
\hline No. of cows & 12 & 12 & & \\
\hline \multicolumn{4}{|l|}{ Previous 305 -d mature } & 0.32 \\
\hline Days on treatment & 42.1 & 42.0 & 1.5 & 0.97 \\
\hline Lactation no. $^{2}$ & 1.9 & 1.9 & 0.30 & 0.99 \\
\hline \multicolumn{5}{|l|}{$\mathrm{BW}, \mathrm{kg}$} \\
\hline$d-21$ & 765 & 754 & 12.6 & 0.54 \\
\hline d 0 & 692 & 688 & 13.6 & 0.84 \\
\hline d 28 & 645 & 643 & 12.9 & 0.92 \\
\hline d 70 & 667 & 673 & 14.3 & 0.77 \\
\hline \multicolumn{5}{|l|}{$\mathrm{BCS}^{3}$} \\
\hline $\mathrm{d}-21$ & 3.23 & 3.20 & 0.07 & 0.80 \\
\hline d 0 & 3.21 & 3.06 & 0.07 & 0.15 \\
\hline d 28 & 2.91 & 2.95 & 0.08 & 0.70 \\
\hline d 70 & 2.97 & 3.02 & 0.08 & 0.65 \\
\hline Calf BW, kg & 41.8 & 45.8 & 2.5 & 0.28 \\
\hline Calving difficulty ${ }^{4}$ & 1.6 & 1.7 & 0.35 & 0.90 \\
\hline DMI d -21 to $0, \mathrm{~kg} / \mathrm{d}$ & 12.5 & 11.9 & 0.58 & 0.41 \\
\hline \multicolumn{5}{|l|}{${ }^{1}$ Significance of $F$-test. } \\
\hline${ }^{2}$ Lactation number be & e calving. & & & \\
\hline${ }^{3}$ Wildman et al., 1982 & & & & \\
\hline
\end{tabular}

cant, and continuing until all remaining variables were significant. Prepartum and postpartum data were analyzed separately.

Statistical significance was declared at $P<0.05$, with trends noted at $P>0.05$ to $P<0.10$. Least squares means and SEM are reported for all data. Significance of interactions are reported when significant. When significant effects among dietary treatments existed, mean separation was conducted by the PDIFF option in SAS.

\section{RESULTS}

Initial cow characteristics are shown in Table 3. Average previous 305-d mature equivalent milk yield was $11,952 \mathrm{~kg}$ and was not different between treatments. Body weights and condition at $21 \mathrm{~d}$ before expected calving date were similar among all animals. Days on treatment and number of lactations before initiation of treatments were similar between treatments and averaged $42.1 \pm 1.5 \mathrm{~d}$ and $1.9 \pm 0.30$ lactations, respectively. Average prepartum DMI was not affected by diet and averaged $12.2 \pm 0.58 \mathrm{~kg} / \mathrm{d}$. Prepartum decrease in DMI (calculated as average DMI during wk 2 prepartum average DMI during wk 1 prepartum) was greater $(P$ $<0.03$ ) for cows fed AMA relative to control cows (Figure 1).

Postpartum performance data are presented in Table 4. Postpartum DMI was not affected by the addition of 


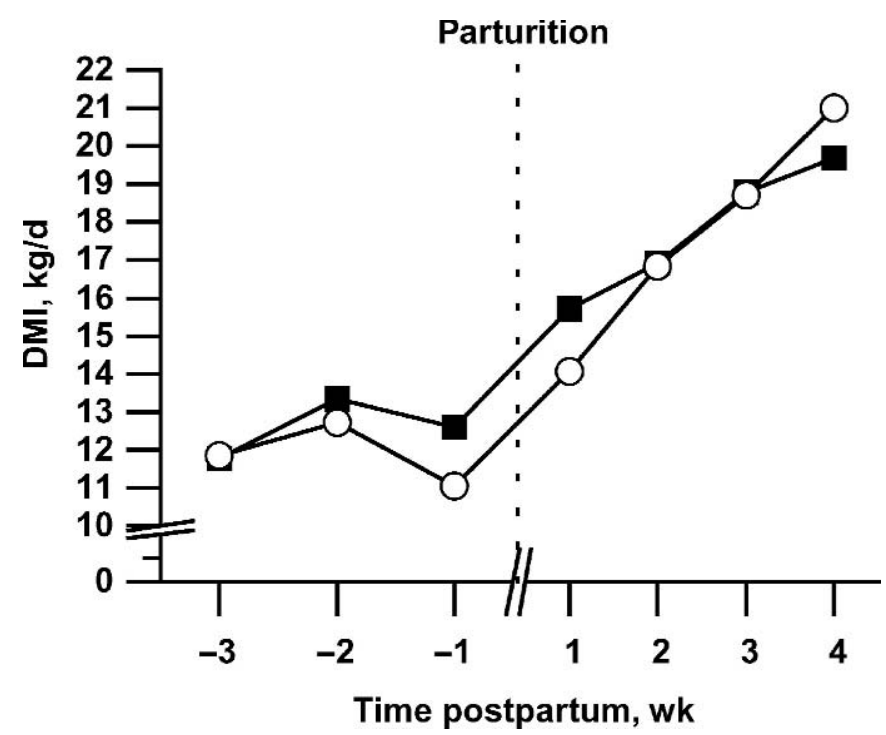

Figure 1. Dry matter intake (pooled SEM = 1.16) of cows fed a control diet (ם) and cows fed a diet supplemented with $\alpha$-amylase ( $\bigcirc$ ).

$\alpha$-amylase, averaging $17.8 \pm 0.74 \mathrm{~kg} / \mathrm{d}$ during the first 21 DIM. Milk, energy-corrected milk (Orth, 1992), and production efficiencies (energy-corrected milk/DMI) were similar among treatments during the first 21 DIM. Milk composition was unaffected by dietary treatments. Milk yield through 70 DIM averaged $43.9 \pm 1.9 \mathrm{~kg} / \mathrm{d}$ and was not affected by dietary treatments (Figure 2).

Effects of treatments on plasma metabolites are presented in Table 5 and plotted over time in Figures 3

Table 4. Postpartum DMI, milk yield, milk composition, milk SCC, $\mathrm{BW}$, and BCS of cows fed a control diet and a diet supplemented with $\alpha$-amylase (AMA).

\begin{tabular}{lccrr}
\hline & \multicolumn{2}{c}{ Diet } & & \\
\cline { 2 - 3 } Item & Control & AMA & SEM & $P^{1}$ \\
\hline DMI d 1 to 21, kg/d & 17.8 & 17.7 & 0.74 & 0.92 \\
Milk d 1 to 21, kg/d & 38.5 & 38.1 & 1.97 & 0.91 \\
ECM ${ }^{2}$ d 1 to 21, kg/d & 41.3 & 40.2 & 2.51 & 0.76 \\
ECM/DMI & 2.85 & 2.41 & 0.22 & 0.17 \\
Milk composition, d 1 to 21 & & & & \\
Fat, \% & 4.78 & 4.18 & 0.26 & 0.13 \\
Fat kg/d & 1.69 & 1.52 & 0.11 & 0.32 \\
True protein, \% & 3.06 & 3.12 & 0.11 & 0.72 \\
True protein, kg/d & 1.16 & 1.07 & 0.07 & 0.39 \\
SNF, \% & 8.42 & 8.65 & 0.16 & 0.33 \\
SNF, kg/d & 3.07 & 3.18 & 0.14 & 0.62 \\
Lactose, \% & 4.80 & 4.74 & 0.13 & 0.76 \\
Lactose, kg/d & 1.82 & 1.74 & 0.09 & 0.52 \\
SCC, $\times 10^{3} / \mathrm{mL}$ & 415 & 125 & 226 & 0.37 \\
Urea N, mg/dL & 11.45 & 10.51 & 0.80 & 0.42 \\
Milk yield d 1 to70, kg/d & 43.6 & 44.2 & 1.90 & 0.83 \\
\hline
\end{tabular}

\footnotetext{
${ }^{1}$ Significance of $F$-test.

${ }^{2} \mathrm{ECM}=$ Energy-corrected milk: $[(0.327 \times \mathrm{kg}$ of milk $)+(12.95 \times \mathrm{kg}$ of fat $)+(7.2 \times \mathrm{kg}$ of protein $)$; Orth, 1992 .
}

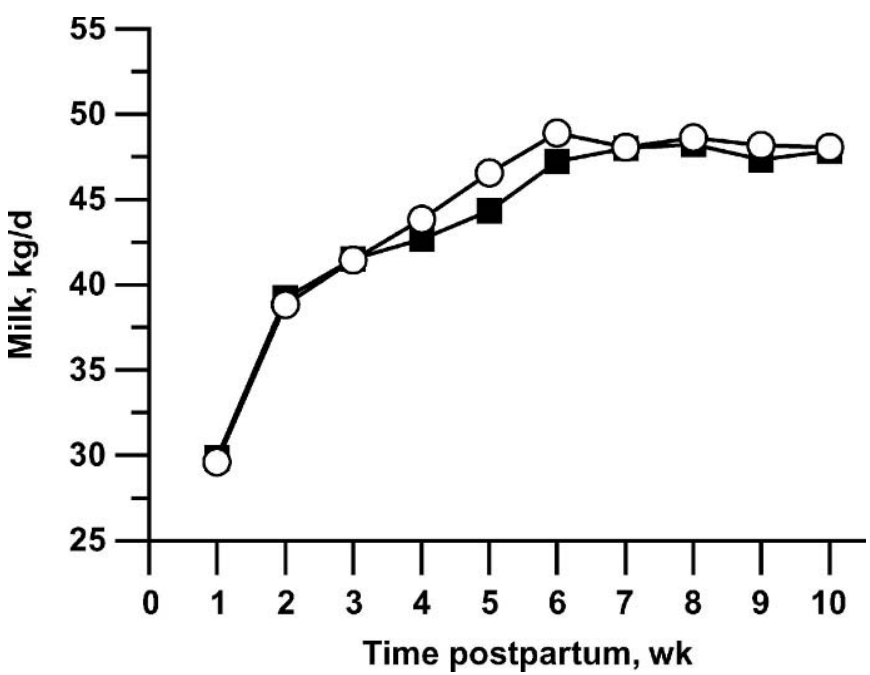

Figure 2. Milk yield (pooled SEM $=2.3$ ) of cows fed a control diet (匹) and cows fed a diet supplemented with $\alpha$-amylase (O).

and 4. Concentrations of glucose in plasma tended ( $P$ $<0.08$ ) to be greater for AMA in samples collected postpartum but not prepartum $(P>0.10)$. Concentrations of glucose in plasma of cows fed the control diet were at the lowest average value for days samples were collected at 14 DIM $(64.6 \mathrm{mg} / \mathrm{dL})$, which was lower $(P<$ $0.04)$ than for cows fed AMA (71.0 mg/dL). Although differences in plasma glucose existed, concentrations of insulin in plasma were unaffected by dietary treatments both pre- and postpartum.

Prepartum, but not postpartum, concentrations of NEFA and BHBA in plasma were greater (3.2 and 1.6 times greater, respectively; $P<0.01$ ) in cows fed AMA relative to those fed the control diet. Measured concen-

Table 5. Plasma glucose, insulin, NEFA, and BHBA and liver composition of cows fed a control diet and a diet supplemented with $\alpha$ amylase (AMA).

\begin{tabular}{|c|c|c|c|c|}
\hline \multirow[b]{2}{*}{ Item } & \multicolumn{2}{|c|}{ Diet } & \multirow[b]{2}{*}{ SEM } & \multirow[b]{2}{*}{$P^{1}$} \\
\hline & Control & AMA & & \\
\hline \multicolumn{5}{|l|}{ Glucose, $\mathrm{mg} / \mathrm{dL}$} \\
\hline Prepartum & 68.9 & 71.5 & 3.04 & 0.56 \\
\hline Postpartum & 64.0 & 69.3 & 2.01 & 0.08 \\
\hline \multicolumn{5}{|l|}{ Insulin, $\mathrm{pg} / \mathrm{mL}$} \\
\hline Prepartum & 366 & 329 & 56 & 0.64 \\
\hline Postpartum & 171 & 177 & 17 & 0.81 \\
\hline \multicolumn{5}{|l|}{ NEFA, $\mu \mathrm{Eq} / \mathrm{L}$} \\
\hline Prepartum & 115 & 373 & 63 & 0.01 \\
\hline Postpartum & 535 & 474 & 50 & 0.41 \\
\hline \multicolumn{5}{|l|}{$\mathrm{BHBA}, \mathrm{mg} / \mathrm{dL}$} \\
\hline Prepartum & 3.91 & 6.28 & 0.46 & $<0.01$ \\
\hline Postpartum & 9.32 & 10.31 & 1.43 & 0.64 \\
\hline Liver lipid, \% wet weight & 13.71 & 12.54 & 1.82 & 0.65 \\
\hline Liver glycogen, $\%$ wet weight & 3.25 & 3.98 & 0.66 & 0.45 \\
\hline
\end{tabular}

${ }^{1}$ Significance of $F$-test. 

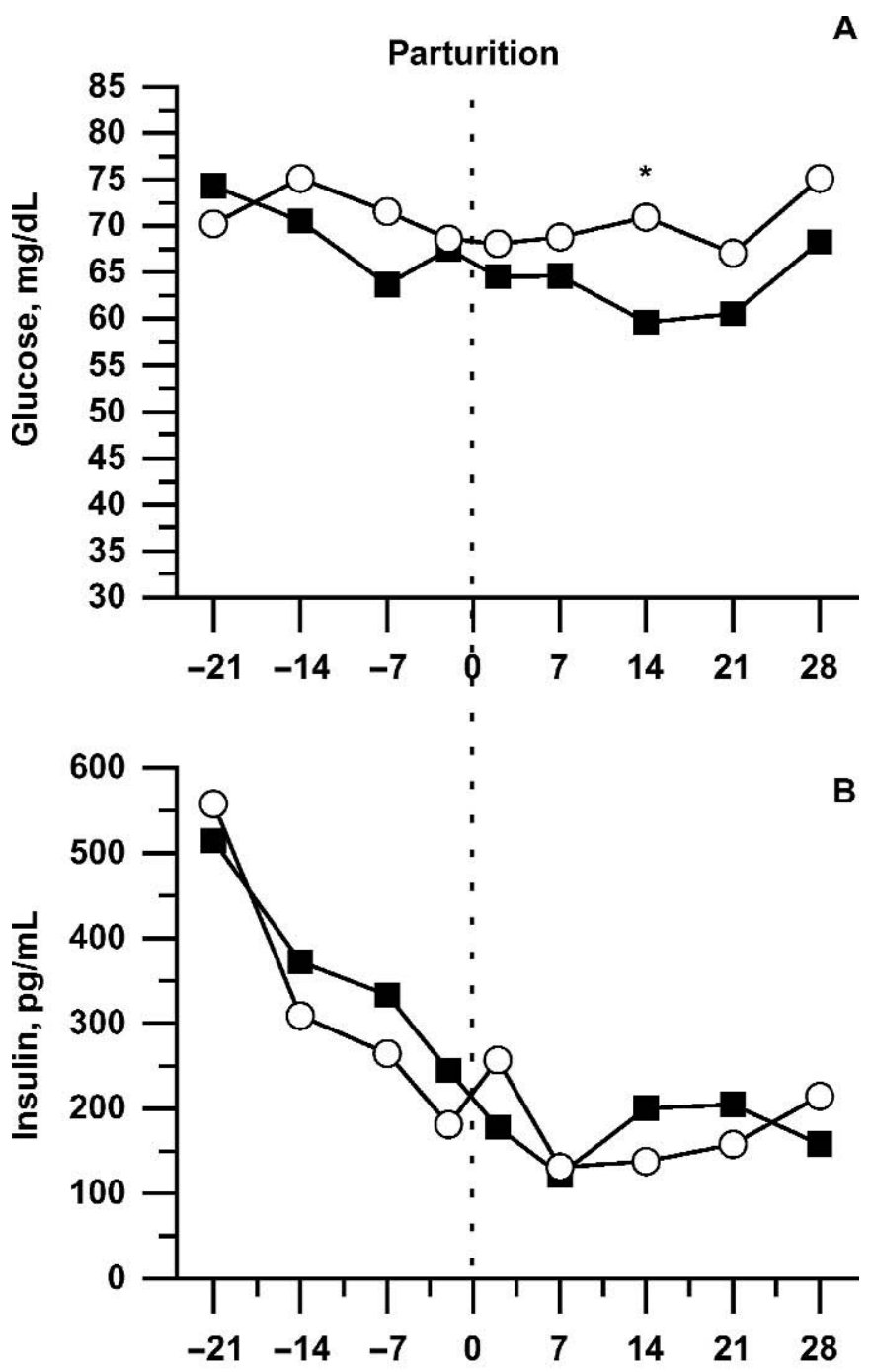

Time postpartum, $d$

Figure 3. Plasma glucose (A) and insulin (B) concentrations (pooled SEM = 4.15 and 56.1, respectively) of cows fed a control diet (ם) and cows fed a diet supplemented with $\alpha$-amylase $(\bigcirc)$. Differences at individual times are indicated by $*(P<0.05)$.

trations of NEFA in plasma were greatest at 2 DIM for both treatments, and declined thereafter. Though apparently this decline was more rapid in cows fed AMA, postpartum differences were not significant (Figure 4A). Although feeding cows AMA increased BHBA in plasma prepartum, these effects were not observed postpartum. Increasing concentrations of BHBA at 21 DIM in cows fed AMA (Figure 4), even if notable, did not become significant until $\mathrm{d} 28$, and postpartum average BHBA were not different $(P=0.64)$. Dietary treatments did not alter liver lipid or glycogen content, which averaged 13.1 and $3.62 \%$, respectively (wet weight; Table

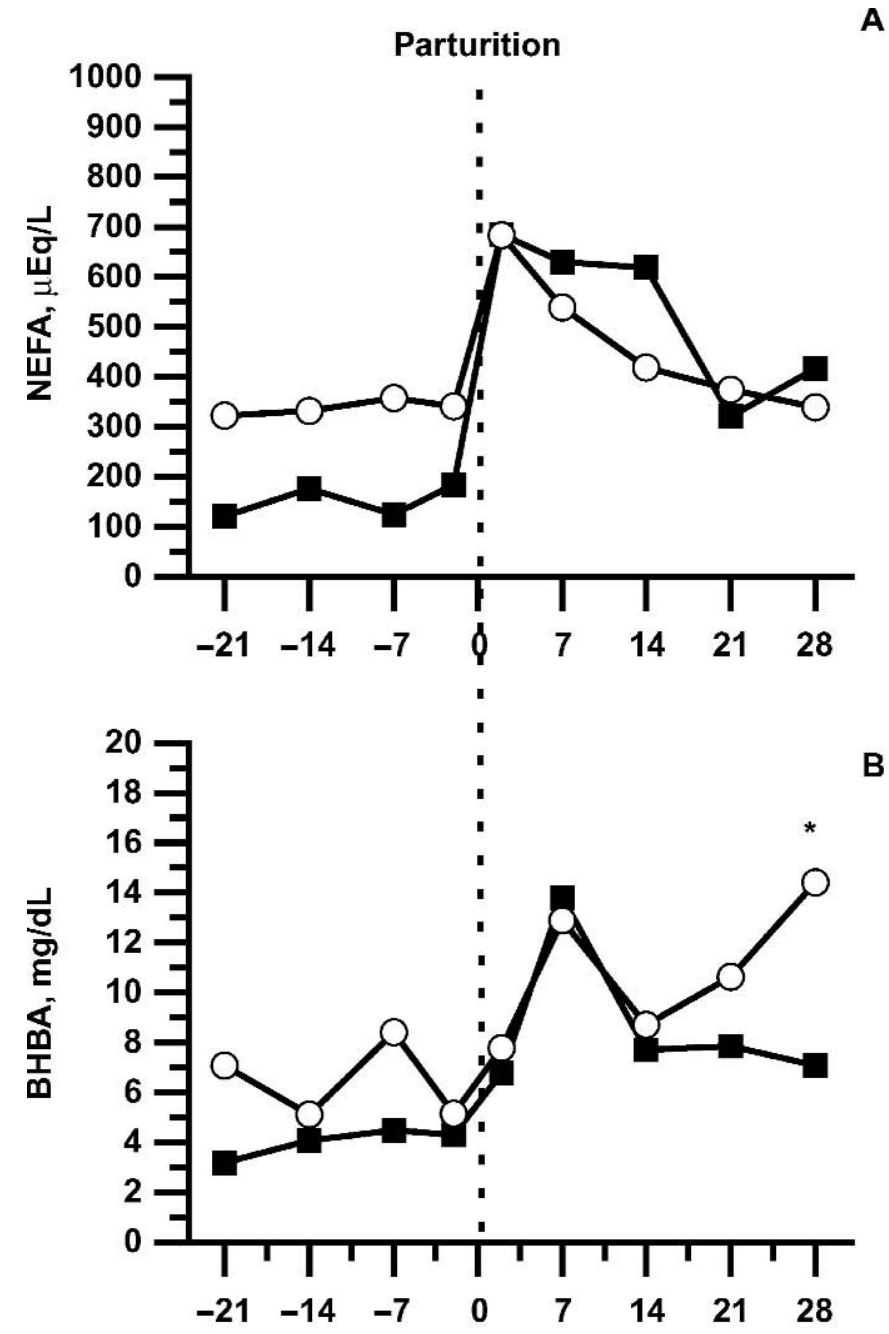

Time postpartum, $d$

Figure 4. Plasma NEFA (A) and BHBA (B) concentrations (pooled SEM = 103 and 2.39 , respectively) of cows fed a control diet ( $\mathbf{\square})$ and cows fed a diet supplemented with $\alpha$-amylase $(\bigcirc)$. Differences at individual times are indicated by $*(P<0.05)$.

5) and there were no effects of day of sample collection or interactions on concentrations of either component.

Effects of diets on ruminal $\mathrm{NH}_{3}-\mathrm{N}$ concentrations and VFA proportions are presented in Table 6. Cows fed AMA had numerically $(P<0.14)$ greater molar proportions of rumen butyrate prepartum but not postpartum. Diet by day ( 21 vs. $7 \mathrm{~d}$ prepartum) interactions were noted for prepartum $\mathrm{NH}_{3}-\mathrm{N}$ concentrations $(P<0.05)$, molar proportions of rumen propionate $(P<0.04)$, and the acetate to propionate ratio $(P<0.04)$. From 21 to $7 \mathrm{~d}$ prepartum, $\mathrm{NH}_{3}-\mathrm{N}$ concentrations and proportions of propionate decreased in cows fed AMA (4.19 to 2.44 $\mathrm{mg} / \mathrm{dL}$ and 20.4 to $18.4 \%$, respectively) relative to those fed the control diet (3.09 to $3.41 \mathrm{mg} / \mathrm{dL}$ and 19.4 to 
Table 6. Ruminal $\mathrm{NH}_{3}-\mathrm{N}$ and VFA proportions of cows fed a control diet and a diet supplemented with $\alpha$-amylase (AMA).

\begin{tabular}{|c|c|c|c|c|}
\hline \multirow[b]{2}{*}{ Item } & \multicolumn{2}{|c|}{ Diet } & \multirow[b]{2}{*}{ SEM } & \multirow[b]{2}{*}{$P^{1}$} \\
\hline & Control & AMA & & \\
\hline \multicolumn{5}{|l|}{ Prepartum } \\
\hline $\mathrm{NH}_{3}-\mathrm{N}, \mathrm{mg} / \mathrm{dL}^{2}$ & 3.25 & 3.31 & 0.36 & 0.90 \\
\hline Total VFA, $\mathrm{m} M$ & 45.9 & 52.9 & 4.2 & 0.24 \\
\hline \multicolumn{5}{|l|}{ VFA, molar proportions } \\
\hline Acetate & 68.3 & 68.0 & 0.68 & 0.73 \\
\hline Propionate $^{2}$ & 19.6 & 19.4 & 0.38 & 0.76 \\
\hline Isobutyrate & 0.78 & 0.73 & 0.11 & 0.75 \\
\hline Butyrate & 9.14 & 10.0 & 0.41 & 0.14 \\
\hline Isovalerate & 1.13 & 0.91 & 0.11 & 0.18 \\
\hline Valerate & 1.05 & 0.95 & 0.11 & 0.55 \\
\hline Branched-chain fatty acids & 1.92 & 1.65 & 0.21 & 0.37 \\
\hline Acetate:propionate 2 & 3.53 & 3.53 & 0.09 & 0.97 \\
\hline \multicolumn{5}{|l|}{ Postpartum } \\
\hline $\mathrm{NH}_{3}-\mathrm{N}, \mathrm{mg} / \mathrm{dL}$ & 2.69 & 2.76 & 0.52 & 0.93 \\
\hline Total VFA, $\mathrm{m} M$ & 40.8 & 46.2 & 4.11 & 0.36 \\
\hline \multicolumn{5}{|l|}{ VFA, molar proportions } \\
\hline Acetate & 63.7 & 62.4 & 1.25 & 0.48 \\
\hline Propionate & 22.5 & 23.0 & 0.95 & 0.75 \\
\hline Isobutyrate & 1.04 & 0.88 & 0.15 & 0.46 \\
\hline Butyrate & 10.3 & 11.0 & 0.67 & 0.50 \\
\hline Isovalerate & 1.24 & 1.30 & 0.16 & 0.82 \\
\hline Valerate & 1.16 & 1.46 & 0.14 & 0.14 \\
\hline Branched-chain fatty acids & 2.28 & 2.18 & 0.30 & 0.81 \\
\hline Acetate:propionate & 2.99 & 2.75 & 0.22 & 0.46 \\
\hline
\end{tabular}

${ }^{1}$ Significance of $F$-test.

${ }^{2}$ Diet by day effect $(P<0.05)$.

$19.7 \%$, respectively). Accordingly, the ratio of ruminal acetate to propionate increased from 21 to $7 \mathrm{~d}$ prepartum in cows fed AMA (3.33 to 3.74) compared with control cows (3.60 to 3.46). All other ruminal fermentation profiles were similar between treatments.

\section{DISCUSSION}

The physiological and metabolic challenges encompassing the transition period in dairy cattle have been described in numerous review papers. The transition period in dairy cattle is characterized by energy deficit as lactation is initiated. According to Beauchemin et al. (2003), the amount of response observed in ruminants fed exogenous enzymes is maximal during times of compromised fiber digestion and energy limitation, which often accompanies the transition period of dairy cattle. This forms the basic premise behind the present investigation in characterizing the effects of an $\alpha$-amylase preparation in diets of transition dairy cows. The amount of enzyme preparation fed was determined from Tricarico et al. (2002) who supplemented cows with $0,12,24$, and $36 \mathrm{~g} / \mathrm{d}$ of the preparation and found milk yield and ruminal starch digestibility to respond quadratically, being highest in cows fed $12 \mathrm{~g} / \mathrm{d}$, whereas DMI was unaffected. In addition, Tricarico et al. (2002) found concentrations of glucose in plasma to be greater for cows fed 0 and $12 \mathrm{~g} / \mathrm{d}$ relative to those fed 24 and $36 \mathrm{~g} / \mathrm{d}$ of the enzyme preparation.

Decreases in prepartum feed intake should be avoided to minimize the likelihood of elevated plasma NEFA and liver triglycerides (Bertics et al., 1992). Based upon this concept, the decrease in DMI and increase in NEFA and BHBA observed from wk 3 to wk 1 prepartum in cows fed AMA should have negatively affected metabolic indicators and lactation performance. The absence of any negative effects on these metabolites and liver lipids and improved glucose status postpartum in cows fed AMA suggests beneficial effects of $\alpha$-amylase on nutrient digestion and absorption after parturition and adaptation to the enzyme. The $\alpha$-amylase fed in the present study is known to increase starch digestibility (Tricarico et al., 2002) and therefore could have provided an improvement in nutrient supply in cows fed AMA. This is further supported by Allen (2000) who indicated that the site of starch digestion determines the form (glucose vs. propionate) of metabolic fuel absorbed, which affects DMI because propionate is more hypophagic than glucose. Other researchers have fed amylase-containing enzyme preparations and observed only small increases $(<1 \%$; Burroughs et al., 1960) or no effect (Rust et al., 1963; Tricarico et al., 2002) in DMI. Therefore, it is likely that improvements in postpartum metabolic indicators (plasma glucose in the present study) are a result of the enzyme on improved nutrient availability resulting from increased digestibility of feedstuffs or increased ruminal absorptive capacity (Dirksen et al., 1985; Xu and Allen, 1998).

The $\alpha$-amylase (Tricarico et al., 2002) or amylasecontaining (Hristov et al., 2000) supplements have been observed to increase the proportion of ruminal butyrate, which was not significantly increased in the current study. Because of collection of samples through esophageal tube, low frequency of collection, and numbers of cows in the present study, increases in ruminal butyrate, although numerically present, may not have been detectable at levels providing significance $(P<0.14$ and $P<0.50$ for pre- and postpartum, respectively). Furthermore, ruminal butyrate is extensively metabolized to BHBA by the rumen epithelium (Weigand et al., 1975) and any increases in butyrate concentrations in rumen fluid may have been offset by the rate of metabolism to BHBA. Previous research (DeFrain et al., 2004) demonstrated increased plasma concentrations of BHBA when lactating dairy cows were fed diets enriching butyrate concentrations in rumen fluid. The research by DeFrain et al. (2004) also demonstrated decreased concentrations of $\mathrm{NH}_{3}-\mathrm{N}$ and tendencies for decreased ruminal propionate in the presence of butyrate-inducing diets. The decreased concentrations of these fermenta- 
tion products in rumens of cows fed AMA in this study, demonstrated by significant diet $x$ day interactions, indicate a similar response that may have been delayed by adaptation to the amylase-containing diets. Postpartum, however, after full adaptation should have occurred, there were no effects of diet on ruminal propionate or $\mathrm{NH}_{3}-\mathrm{N}$.

Tricarico et al. (2002) observed increases in yields of milk, milk fat, and milk protein in cows supplemented with $12 \mathrm{~g} / \mathrm{d}$ of $\alpha$-amylase relative to an unsupplemented control group. Field trials conducted by Harrison and Tricarico (2004) found that supplementing cows with $12 \mathrm{~g} / \mathrm{d}$ of an amylase preparation increased yields of milk and milk protein, had no effect on milk fat yield, and decreased milk fat percentage. The numerical decrease in milk fat content in the present study, although not significant, is in general agreement with results observed by Harrison and Tricarico (2004) but contradictory to the findings of Tricarico et al. (2002). The $\alpha$ amylase (Tricarico et al., 2002) or amylase-containing (Hristov et al., 2000) supplements have increased the concentration of ruminal butyrate, giving rise to precursors necessary for fatty acid synthesis by the mammary gland. The lack of dietary effect on milk fat in the present study may have been attributable to failure to significantly increase ruminal butyrate production. Alternatively, differences between our study and the increases in milk fat reported by Tricarico et al. (2002) could have been attributable to stage of lactation. In the current study with early lactation cows, milk fat concentrations are frequently driven by delivery of NEFA to the mammary gland. Cows fed AMA had numerical decreases in concentrations of NEFA postpartum that corresponded with a numerical decrease in milk fat in the same cows.

With the exception of plasma glucose, changes in plasma metabolites observed in the present study are in general agreement with the findings of Tricarico et al. (2002). Cows fed AMA tended to have greater concentrations of glucose in plasma, whereas Tricarico et al. (2002) found incremental increases $(0,12,24$, or $36 \mathrm{~g} /$ d) in the amount of $\alpha$-amylase to linearly $(P<0.01)$ decrease plasma glucose. Differences between the present study and that of Tricarico et al. (2002) might have been attributable to the composition of experimental diets. Diets used in the current study contained half as much haylage and twice as much corn silage as diets fed by Tricarico et al. (2002). These differences resulted in a greater calculated $\mathrm{NE}_{\mathrm{L}}(1.72$ vs. $1.60 \mathrm{Mcal} / \mathrm{kg})$ for cows fed AMA relative to the diet fed by Tricarico et al. (2002). In combination, differences in diets and stage of lactation along with decreased DMI, $5 \mathrm{~kg} / \mathrm{d}$ less in the current experiment, resulted in differences in rumen fermentation profiles and therefore, differences in plasma metabolites.

Alternatively, gluconeogenic activity may have been affected by prepartum increases in BHBA observed in this experiment because BHBA is metabolized to acetylCoA, an allosteric activator of pyruvate carboxylase (Utter and Keech, 1963), which converts pyruvate to oxaloacetate during hepatic gluconeogenesis. Black et al. (1966) indicated that butyrate metabolism spares the oxidation of pyruvate, a glucogenic precursor, and enhances the conversion of pyruvate to oxaloacetate. In support of conclusions from Black et al. (1966), tracer work by Anand and Black (1970) found butyrate injections to stimulate gluconeogenesis in cattle. In this experiment, increases in blood glucose observed prepartum when plasma BHBA was increased were not significant. Blood glucose was increased at 14 DIM, however, indicating either improved nutrient delivery for hepatic gluconeogenesis or "activation" of gluconeogenic enzymes as described.

Similar to our results, Tricarico et al. (2002) found cows fed $\alpha$-amylases to have increased concentrations of plasma BHBA. Increased plasma BHBA in amylasesupplemented diets is thought to be attributable to rumen epithelial metabolism of the increased proportions of ruminal butyrate to BHBA before release into portal circulation (Weigand et al., 1975). The increased BHBA observed in this study prepartum may have also been attributable to partial hepatic oxidation of increased concentrations of plasma NEFA observed prepartum in response to decreased DMI.

According to data from Nielen et al. (1994), plasma BHBA concentrations greater than $12.5 \mathrm{mg} / \mathrm{dL}$ indicate cows with subclinical ketosis. The greatest concentration of BHBA (14.4 mg/dL) was observed in cows fed AMA at 28 DIM, 1 wk after feeding AMA was discontinued and all cows began receiving a common diet. During this period, milk yield increased in cows fed AMA and continued to increase through $7 \mathrm{wk}$ of lactation (Figure 2). The increasing BHBA after the first 14 DIM may reflect differences in stage of lactation and DMI. If amylase feeding had continued, plasma metabolite proportions may have been similar to those observed by Tricarico et al. (2002) with increased BHBA as a result of carryover effects of enzyme on ruminal fermentation patterns.

\section{CONCLUSIONS}

Supplementing diets for transition dairy cows with $\alpha$-amylase resulted in differences in key metabolic indicators whereas effects on lactation performance were minimal. The magnitude of DMI depression from 2 to 1 wk before parturition was greater in cows fed AMA 
relative to cows fed the control diet; however, cows performed similarly during the postpartum phase of the experiment. Plasma glucose profiles suggest supplementing cows with an $\alpha$-amylase is beneficial, especially considering the glucose demand at the initiation of lactation. The increased concentrations of plasma BHBA and NEFA prepartum and glucose postpartum demonstrate improved energy balance and greater ability to maintain blood glucose concentrations, consistent with demands for lactation and the perceived goals of nutrition for the transition dairy cow.

\section{ACKNOWLEDGMENTS}

Partial funding was provided by Alltech, Inc. (Nicholasville, KY) and the South Dakota Agricultural Experiment Station. The authors express appreciation to personnel at the South Dakota State University Dairy Teaching and Research Farm for the feeding and care of the animals.

\section{REFERENCES}

Allen, M. S. 2000. Effects of diet on short-term regulation of feed intake by lactating dairy cattle. J. Dairy Sci. 83:1598-1624.

Anand, R. S., and A. L. Black. 1970. Species differences in the glucogenic behavior of butyrate in lactating ruminants. Comp. Biochem. Physiol. 33:129-142.

Association of Official Analytical Chemists. 1990. Official Methods of Analysis. 15th ed. AOAC, Arlington, VA.

Association of Official Analytical Chemists. 1997. Official Methods of Analysis. 16th ed. AOAC Int., Gaithersburg, MD.

Beauchemin, K. A., D. Colombatto, D. P. Morgavi, and W. Z. Yang. 2003. Use of exogenous fibrolytic enzymes to improve feed utilization by ruminants. J. Anim. Sci. 81(Suppl. 2):E37-E47.

Bertics, S. J., R. R. Grummer, C. Cadorniga-Valino, and E. E. Stoddard. 1992. Effect of prepartum dry matter intake on liver triglyceride concentration and early lactation. J. Dairy Sci. 75:19141922.

Black, A. L., J. Luick, F. Moller, and R. S. Anand. 1966. Pyruvate and propionate metabolism in lactating cows. Effect of butyrate on pyruvate metabolism. J. Biol. Chem. 241:5233-5237.

Burroughs, W., W. Woods, S. A. Ewing, J. Greig, and B. Theurer. 1960. Enzyme additions to fattening cattle rations. J. Anim. Sci. 19:458-464.

DeFrain, J. M., A. R. Hippen, K. F. Kalscheur, and D. J. Schingoethe. 2004. Feeding lactose increases ruminal butyrate and plasma $\beta$ hydroxybutyrate in lactating dairy cows. J. Dairy Sci. 87:24862494.

Derling, L. E., D. E. Brown, L. Castle, and L. Kelly. 1987. Muscle glycogen: Comparison of iodine binding and enzyme digestion assays and application to meat samples. Meat Sci. 20:167-177.

Dirksen, G. U., H. G. Liebich, and E. Mayer. 1985. Adaptive changes of the ruminal mucosa and their functional and clinical significance. Bovine Pract. 20:116-120.

Harrison, G. A., and J. M. Tricarico. 2004. Effects of a supplemental amylase enzyme preparation on lactational performance in com- mercial dairy herds. 1. Whole herd responses. J. Dairy Sci. 87(Suppl. 1):50. (Abstr.)

Holm, J., I. Bjorck, A. Drews, and N. G. Asp. 1986. A rapid method for the analysis of starch. Starch 7:224-226.

Hristov, A. N., T. A. McAllister, and K. Cheng. 2000. Intraruminal supplementation with increasing levels of exogenous polysaccharide-degrading enzymes: Effects on nutrient digestion in cattle fed a barley grain diet. J. Anim. Sci. 78:477-487.

Huntington, G. B. 1997. Starch utilization by ruminants: From basics to the bunk. J. Anim. Sci. 75:852-867.

Johnson, M. J., and J. P. Peters. 1993. Technical note: An improved method to quantify nonesterified fatty acids in bovine plasma. J. Anim. Sci. 71:753-756.

Littell, R. C., G. A. Milliken, S. W. Walter, and R. D. Wolfinger. 1996. SAS Systems for Mixed Models. SAS Institute, Inc., Cary, NC.

Mills, S. E., D. C. Beitz, and J. W. Young. 1986. Characterization of metabolic changes during protocol for inducing lactation ketosis in dairy cows. J. Dairy Sci. 69:352-361.

National Research Council. 2001. Nutrient Requirements of Dairy Cattle. 7th rev. ed. Natl. Acad. Sci., Washington, DC.

Nielen, M., M. G. A. Aarts, A. G. M. Jonkers, T. Wensing, and Y. H. Schukken. 1994. Evaluation of two cowside tests for the detection of subclinical ketosis in dairy cows. Can. Vet. J. 35:229-232.

Orth, R. 1992. Sample Day and Lactation Report. DHIA 200 Fact Sheet A-2. Mid-States DRPC, Ames, IA

Owens, F. N., D. S. Secrist, W. J. Hill, and D. R. Gill. 1998. Acidosis in cattle: A review. J. Anim. Sci. 76:275-286.

Ralston, A. T., D. C. Church, and J. E. Oldfield. 1962. Effect of enzymes on digestibility of low quality roughage. J. Anim. Sci. 21:306-308.

Rowe, J. B., M. Choct, and D. W. Pethick. 1999. Processing cereal grains for animal feeding. Aust. J. Agric. Res. 50:721-736.

Rust, J. W., N. L. Jacobson, and A. D. McGilliard. 1963. Supplementation of dairy calf diets with enzymes. I. Effects on rate of growth. J. Anim. Sci. 22:1104-1108.

SAS Institute. 2001. SAS User's Guide. Statistics, Version 8.01 ed. SAS Inst., Inc., Cary, NC.

Smith, T. R., A. R. Hippen, D. C. Beitz, and J. W. Young. 1997. Metabolic characteristics of induced ketosis in normal and obese dairy cows. J. Dairy Sci. 80:1569-1581.

Tricarico, J. M., J. D. Johnston, and K. A. Dawson. 2002. The influence of low concentrations of supplemental enzymes on ruminal fermentation and milk production in dairy cows. J. Dairy Sci. 85(Suppl. 1):105. (Abstr.)

Trinder, P. 1969. Determination of glucose in blood using glucose oxidase with an alternative oxygen acceptor. Ann. Clin. Biochem. 6:24-27.

Utter, M. F., and D. B. Keech. 1963. Pyruvate carboxylase. I. Nature of the reaction. J. Biol. Chem. 238:2603-2608.

Van Soest, P. J., J. B. Robertson, and B. A. Lewis. 1991. Methods for dietary fiber, neutral detergent fiber, and nonstarch polysaccharides in relation to animal nutrition. J. Dairy Sci. 74:35833597.

Weigand, E., J. W. Young, and A. D. McGilliard. 1975. Volatile fatty acid metabolism by rumen mucosa from cattle fed hay or grain. J. Dairy Sci. 58:1294-1300.

Wildman, E. E., G. M. Jones, P. E. Wagner, R. L. Bowman, H. F. Troutt, Jr., and T. N. Lesch. 1982. A dairy cow body condition scoring system and relationship to selected production characteristics. J. Dairy Sci. 65:495-501.

Williamson, D. H., J. Mellanby, and H. A. Krebs. 1962. Enzymatic determination of $\mathrm{D}(-) \beta$-hydroxybutyrate and acetoacetic acid in blood. Biochem. J. 82:90-96.

Xu, J., and M. S. Allen. 1998. Effects of dietary lactose compared with ground corn on growth rate of rumen papillae. J. Dairy Sci. 81(Suppl. 1):1158. (Abstr.) 